\title{
Editorial
}

\section{Courts as a site of struggle: challenges to the rule of law in South Africa}

It is both ironic and fitting that this $50^{\text {th }}$ edition of SA Crime Quarterly has a strong legal focus, since over the past few years South Africans have increasingly turned to the courts to resolve and adjudicate issues that arguably should have been resolved by other means. While a positive interpretation of this is that the courts and the judiciary have retained the confidence of South Africans, it also suggests that we have run out of other options, and seem unable to resolve political and other crises through negotiation and compromise. This is additionally ironic, since our ability to peacefully negotiate ourselves out of apartheid meant the South African transitional process and the Truth and Reconciliation Commission were hailed as a success all over the world.

In the last edition of Crime Quarterly (SACQ 49), which focused on the challenges of communities in the platinum belt to hold traditional leaders to account, contributors showed how community members who have turned to the courts to resolve disputes with traditional leaders (who are supposed to act in communal interests) have often been left feeling frustrated and helpless. This has led not only to a loss of faith in the criminal justice system but also to an increase in public protest, with equally unsatisfying outcomes.

Be it for rural communities struggling for justice, or political parties seeking to resolve governance crises, such as whether the President is responsible for costs associated with the building of his massive homestead in Nkandla, the courts should be the final arbitrator - applying the law to determine the correct outcome. This is a powerful role - when the litigants accept the rule of law. However, increasingly we are seeing that when the outcome of court cases does not favour the African National Congress (ANC) or those who hold positions of power, the courts offer a means to delay or stall any further action, almost indefinitely. Repeated appeals against judgements take years and a massive financial commitment - they are thus the reserve of those who have access to substantial resources. But in some cases the findings of courts are simply ignored when they don't suit those who hold power. This has been the case in Oudtshoorn in the Western Cape, where, despite court rulings requiring the ANC to step down after having lost its majority in a municipal by-election, the councillors and mayor have refused to do so. Oudtshoorn is only one among several local authorities facing crises of this nature. The power to enforce rulings in situations like this is in the hands of the police, who cannot and should not be pulled into fixing problems that should have been resolved at a political level. Oudtshoorn is just one example of where the rule of law has been flouted; there are unfortunately many others.

The breakdown of the rule of law at local level is dangerous. When the courts can no longer offer resolution, and when the breakdown of the rule of law threatens to, or does in fact, affect the delivery of basic services such as clean water, waste removal and repairs to roads, we will face not only increases in violent public protest but also the possibility of a public health disaster.

In this edition of Crime Quarterly Martin Schönteich shows how political interference in the National Prosecuting Authority and the failure to appoint credible and stable leadership threatens to incapacitate the institution and affects access to justice in lower courts, as it saps morale and undermines the ability of prosecutors to get on with their jobs. 
The two case notes in this edition reflect on two important issues. Phumlani Tyabazayo analyses the Western Cape High Court and Constitutional Court judgements in the case brought by the Minister of Police to prevent the Premier of the Western Cape from establishing a commission of inquiry into policing in Khayelitsha. These judgements have clarified the scope of the oversight function of provincial governments in relation to policing. Since these judgements, the commission has been completed and offered a substantial set of findings and recommendations, which, if implemented, would make a positive difference to policing, at least

in Khayelitsha.

In her case note Zita Hansungule considers the finding of the Constitutional Court that the Criminal Law (Sexual Offences and Related Matters) Amendment Act 32 of 2007 was unconstitutional in that it required names of child offenders to be automatically included on the National Register for Sex Offenders upon conviction of a sexual offence against a child or person with disability. This judgement is significant not only because it relates to the rights of children who come into conflict with the law but also because it provides the lower courts with the basis on which to exercise discretion in cases involving young sex offenders.

We conclude this edition with an article by Douglas Coltart, who draws on South Africa's experience to show how the new Constitution of Zimbabwe might be used to amend the laws relating to rape and sexual offences in that country, and improve justice for survivors.

\section{Chandré Gould (Editor)}

